\title{
屋外空間における短波および長波の放射強度の分布に関する実測 \\ A SURVEY ON THE RADIANT INTENSITY DISTRIBUTION OF THE SHORT AND LONG WAVE ZONES IN OUTDOORS
}

\author{
足. 永靖 信* \\ Yasunobu ASHIE
}

\begin{abstract}
A radiant heat measuring device, which has an automatic spherical tracking system with both sensors of the solar radiation and the infrared radiation, was developed to investigate the thermal distribution in outdoors. First, a calculation method to obtain the mean radiant temperature around a plate and a sphere was given by integrating the spot radiation data in every angle. Then, several outdoor spaces in a forest canopy and building canopies were investigated. The measurement results of the mean radiant temperature corresponds well with the data by the black sphere method with an error of $7 \%$, though this is under a dynamic weather condition.
\end{abstract}

Keywords : Solar Radiation, Infrared Radiation, Radiant Heat, Mean Radiant Temperature, Thermal Sensation 日射、赤外線、放射熱、平均放射温度、温冷感

\section{1.はじめに}

戸外で人々が日陰を追い求める姿は夏の風物といえよう。日射が 温熱感覚に影響することは言うまでもない。しかし、放射熱の場を 把握することは一般に困難である。放射熱は波長域の異なる短波放 射（日射）と長波放射（赤外輻射）に大別さ九る。両者は地表面や 建物等の地物の間で複雑に交錯し、一部は反射し合っている。その 様子は目で捕らえることはできず、実感されにくいのも事実である。 放射熱の発生を建物壁や地表面被覆等の地物単位で把握できれば建 築的方策も採りやすい。屋外空間における放射熱環境の計測はこれ までもいくつか研究報告がなされているが、計測上の制限もあり、 いずれも人体に見立てた球や円筒が受ける日射や長波放射の総熱量 を評価するにとどまっている 122)334)。中村は放射熱流束の方向成分 を検討している5)。これは放射率等の物性值の異なる複数の素子を 有する 6 組の正方形プレートを立方体に組み上げて上下、左右、前 後の長波、短波の放射熱流束を別個に検知しようとするものである。 しかし、地物単位の詳細なスケールで放射熱流束の特性は検討され ていない。本報は、スポット式の放射センサを用いて全球的なトラ バース計測を行い、従来の方法では知り得なかった屋外空間におけ る短波、長波の放射強度の連続的分布を明らかにしたものである。

\section{2. 計楖システム}

計測システムの全体構成を図 1 に示す。全球的に長波長および短 波長の放射強度を計測し、波長毎に放射強度を等距離射影方式でパ
ソコン画面上で可視化し、魚眼画像と照合させることができる。写 真 1 は計測器の外観を表したものである。短・長波長のセンサを搭 載したトラバースを仰角方向および円周角方向に駆動させることに よりあらゆる方向の波長毎放射強度を得ることができる。表 1 にセ ンサの仕様を記す。詳細な分布を短い計測時間で得るために可能な
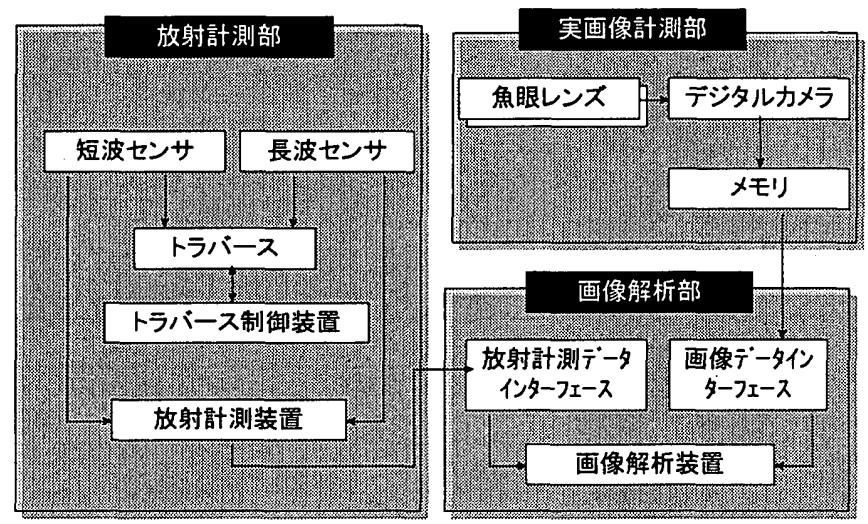

図1 屋外放射熱環境計測システム

表 1 センサ仕様

\begin{tabular}{|c|c|c|c|c|c|}
\hline 項目 & 波長篹囲 & 開口角 & 応答速度 & 精度 & 感度 \\
\hline 短波 & $0.3 \sim 2.6 \mu \mathrm{m}$ & $11 \mathrm{deg}$. & $1 \mathrm{sec}$ & $5 \%$ & $8.33 \mathrm{mV} \cdot \mathrm{m}^{2} \mathrm{str} / \mathrm{W}$ \\
\hline 長波 & $4 \sim 15 \mu \mathrm{m}$ & $11 \mathrm{deg}$. & $1 \mathrm{sec}$ & $7 \%$ & $0.0205 \mathrm{mV} \cdot \mathrm{m}^{2} / \mathrm{W}$ \\
\hline
\end{tabular}

$*$ 建設省建築研究所 主任研究員 · 工博

Chief Research Worker, Building Research Institute, Ministry of Construction, Dr. Eng. 
限り、開口角を絞り、応答性が高いものとした。また、短波センサ は照り返し日射を捕らえるため、高感度タイプとした。半球の計測 メッシュを等距離射影方式で図 2 に示す。計測メッシュ数は半球分 で169点、全球分で 338 点であり、各々の計測メッシュにて短 波、長波の放射強度が求まる仕組みである。半球のスキャン計測時 間は約 4 分半である。全球の計測方式は、上半球の計測終了後、卜 ラバースを反転させて下半球分を実施するものであり、トラバース の反転に要する時間も含めて全体で約 10 分の時間を要する。

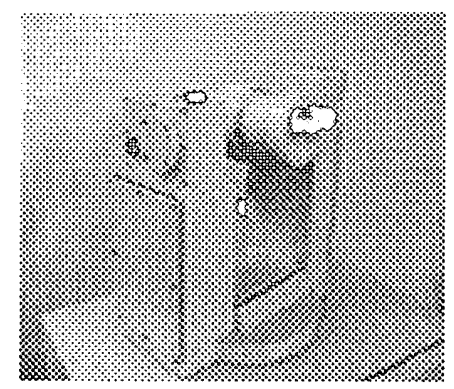

写真 1 計測器外観

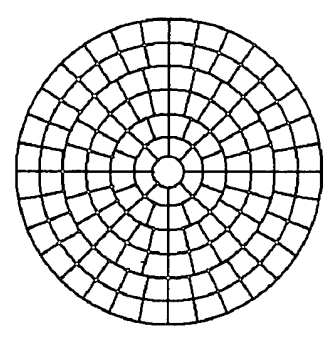

図 2 計測メッシュ (等距離射影方式)

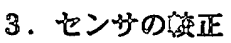

センサ受感部 $d A_{p}$ が周囲メッシュ $A_{r i}$ から受ける短波および長 波の放射熱昷 $Q_{s, \iota}\left\{A_{r i} \rightarrow d A_{p}\right\}$ は次式で表される。

$Q_{s, L}\left\{A_{r i} \rightarrow d A_{p}\right\}=\mathbb{I}_{s,}\left\{A_{r i}\right\} d A_{p} \Omega\left\{d A_{p} \rightarrow A_{r i}\right\}$

$\Omega\left(d A_{p} \rightarrow A_{r i}\right)$ は $d A_{p}$ から $A_{r i}$ を見た立体角の投影であ゙り、セ ンサの開口角から決定される。

短波センサの較正は屋外にて実際の日射を計測し、標淮測器と比 晬する方法によった。標準測器は世界放射基準(WRR)準㯧の直達日 射計を用いた。下式に、センサの電圧出力 $V_{s}$ と標準測器の値を代 入し、センサ定数 $\mathrm{C} s 、 \eta_{\mathrm{s}}$ を求めた。

短波センサの熱流束 =標準測器の值 $\times D=C_{s}+\eta_{s} V_{s}$

Dは標準測器との計測レンジの相違を補正するため、短波センサに 装着したフィルタの日射減衰率で既知の值である。実際の計測時に はフィルタを脱着して使用する。（1）、（2）式より放射強度の 短波成分は次式で表される。

$\mathbb{I}_{s}\left\{A_{r i}\right\}=\frac{Q_{s}\left\{A_{r i} \rightarrow d A_{p}\right\}}{d A_{p} \Omega\left\{d A_{p} \rightarrow A_{r i}\right\}}=\frac{C_{s}+\eta_{s} \mathbb{V}_{s}}{\Omega\left\{d A_{p} \rightarrow A_{r i}\right\}}$

長波センサは温度一様とした黒体炉において較正を行った。黒体 如温度から得られる知表面の放射熱流束 $\sigma T_{r}{ }^{4}$ とセンサの電圧出 カ $V$ しを次式に代入してセンサ定数 $\mathrm{C} 、 \eta$ 。を求めた。

長波センサの熱流束 $=\sigma T_{r}^{4} \Psi\left\{d A_{p} \rightarrow A_{r i}\right\}=C_{l}+\eta_{l} V_{l}$

放射強度の長波成分は次式で表される。

$I_{l}\left\{A_{r i}\right\}=\frac{Q_{l}\left\{A_{r i} \rightarrow d A_{p}\right\}}{d A_{p} \Omega\left\{d A_{p} \rightarrow A_{r i}\right\}}=\frac{C_{l}+\eta_{l} \mathbb{V}_{l}}{\Omega\left\{d A_{p} \rightarrow A_{r i}\right\}}$

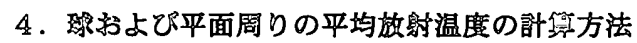

4-1. 局所放的温度

放射強度テータは下記のような局所放射温度に変換できる。

$T_{r i, \iota}=\sqrt[4]{\frac{\pi I_{\iota}\left\{A_{r i}\right\}}{\sigma}}$

$T_{r i}=\sqrt[4]{\frac{\pi\left(I_{s}\left\{A_{r i}\right\}+I_{\iota}\left\{A_{r i}\right\}\right)}{\sigma}}$

式(6.a)に示される局所放射温度 $T r i$, ，は、完全拡散、完全黒体の仮 想面に囲まれた空間における表面温度と解䣋できる。したがって、 現実の空間の温度とは必ずしも一致しない。相互放射、水蒸気の吸 収等様々な過程を経て結果的に計測された長波放射強度を等価温度 に算定するものである。式(6.b)の局所放射温度 $T_{r i}$ は日射影瑟も考 脈した等価温度である。

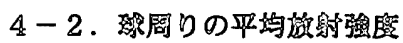

微小球 $g$ と周囲 $A_{r}$ の放射熱流束の収支は次式で表される。

$Q_{s, \iota}\left\{A_{r} \leftrightarrow g\right\} / A_{g}=\sum_{s p h e r e} Q_{s, \iota}\left\{A_{r i} \leftrightarrow g\right\} / A_{g}$

$=\frac{1}{4} \sum_{s p h e r e}\left(I_{s, \iota}\left\{A_{r i}\right\}-I_{s, \iota}\{g\}\right) \Omega\left\{g \rightarrow A_{r i}\right\}$

ここで、 $Q_{s, \iota}\left\{A_{r i} \leftrightarrow g\right\}$ は微小球 $g$ が周囲メッシュ $A_{r i}$ と交換 する短波、長波の放射熱量の収支、 $\Omega(g \rightarrow A r)$ は微小球 $g$ から 見た周囲メッシュ $A_{r i}$ の立体角を表す。半球平均放射強度 $I s, \iota$ (semisphere) 、全球平均放射強度 $I_{s, \iota}$ (sphere) は以下の式で示 される。

$I_{s, \iota}\{$ semisphere $\}=\frac{\sum_{\text {semisphere }} \mathbb{I}_{s, \iota}\left\{A_{r i}\right\} \Omega\left\{g \rightarrow A_{r i}\right\}}{2 \pi}$

$I_{s, \iota}\{$ sphere $\}=\frac{\sum_{s p h e r e} I_{s, \iota}\left\{A_{r i}\right\} \Omega\left\{g \rightarrow A_{r i}\right\}}{4 \pi}$

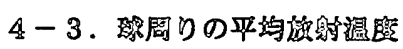

微小球 gの全放射熱流束収支を局所放射温度 $T_{r i}$ で表す。

$\sum_{\text {sphere }}\left(Q_{s}\left\{A_{r i} \leftrightarrow g\right\}+Q_{\iota}\left\{A_{r i} \leftrightarrow g\right\}\right) / A_{g}$

$=\sum_{\text {sphere }}\left(\sigma T_{r i}^{4}-\sigma T_{g}^{4}\right) \Psi\left\{g \rightarrow A_{r i}\right\}$

$=\sum_{\text {sphere }} \sigma K\left\{A_{r i} \leftrightarrow g\right\}\left(T_{r i}-T_{g}\right) \mathbb{P}\left\{g \rightarrow A_{r i}\right\}$

ここで $\kappa\left\{A_{r i \leftrightarrow g}\right\}$ は $A_{r}$ と $g$ の放射熱交換における局所温度係 数であり、次式で定議される。

$\kappa\left\{A_{r i} \leftrightarrow g\right\}=\left(T_{r i}^{2}+T_{g}^{2}\right)\left(T_{r i}+T_{g}\right)$

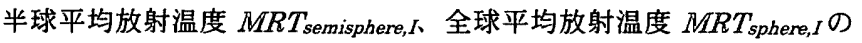
定義を以下に示す。

$M R T_{\text {semisphere, },}=\sqrt[4]{\frac{\pi\left(I_{s}\{\text { semisphere }\}+I_{\iota}\{\text { semisphere }\}\right)}{\sigma}}(11 . a)$ 


$$
M R T_{\text {sphere, } I}=\sqrt[4]{\frac{\pi\left(I_{s}\{\text { sphere }\}+I_{\iota}\{\text { sphere }\}\right)}{\sigma}}
$$

以上が放射強度を積算して平均化を行う方法であるが、放射温度 で積算する方法も考えられる。局所温度係数 $\kappa$ の值は通常の温度条 件では変化が小さい。(9)式において局所温度保数 $\kappa\left\{A_{r i} \leftrightarrow g\right\}$ が 全球で一定と見なせば

$$
\begin{aligned}
& \sum_{\text {sphere }}\left(Q_{s}\left\{A_{r i} \leftrightarrow g\right\}+Q_{\iota}\left\{A_{r i} \leftrightarrow g\right\}\right) / A_{g} \\
& =\sigma \kappa\left[\sum_{\text {sphere }} \Psi\left\{g \rightarrow A_{r i}\right\} T_{r i}-T_{g}\right]
\end{aligned}
$$

したがって、球周りの平均放射温度は局所放射温度を形態俰数 $\Psi\{g$ $\left.\rightarrow A_{r i}\right\}$ で重みづけ積算した形で表される。

$$
M R T_{\text {sphere }, T}=\sum_{\text {sphere }} \Psi\left\{g \rightarrow A_{r i}\right\} T_{r i}
$$

\section{4-4. 平面周りの平均放射强度}

微小面 $d A_{p}$ 之周边 $A_{r}$ の放射熱流束の収支は次式で表される。こ こで、平面とは表裏 2 面のうち 1 面を指し、対象面側の半球分の放 射強度のみを問題とする。

$$
\begin{aligned}
& Q_{s, \iota}\left\{A_{r} \leftrightarrow d A_{p}\right\} / d A_{p}=\sum_{\text {plate }} Q_{s, \iota}\left\{A_{r i} \leftrightarrow d A_{p}\right\} / d A_{p} \\
& =\sum_{\text {plate }}\left(I_{s, \iota}\left\{A_{r i}\right\}-I_{s, \iota}\left\{d A_{p}\right\}\right) \Omega\left\{d A_{p} \rightarrow A_{r i}\right\}
\end{aligned}
$$

球周りの熱流束収支では放射強度を立体角 $\Omega\left\{g \rightarrow A_{r i}\right\}$ で重み付け 積算したのに対して、平面の場合では立体角の投影 $\Omega\left\{d A_{0} \rightarrow A_{n}\right\}$ で重み付归積算を行う。半球の積算による平板周りの平均放射強度

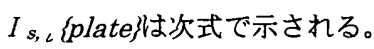

$I_{s, \iota}\{$ plate $\}=\frac{\sum_{\text {plate }} I_{s, L}\left\{A_{r i}\right\} \Omega\left\{d A_{p} \rightarrow A_{r i}\right\}}{\pi}$

\section{4-5. 平面周りの平均放射温度}

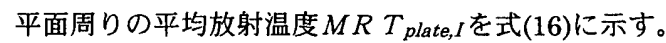

$$
M R T_{\text {plate }, I}=\sqrt[4]{\frac{\pi\left(I_{s}\{\text { plate }\}+I_{\iota}\{\text { plate }\}\right)}{\sigma}}
$$

上式は放射強度の積算により平均化を行う方法である。これに対し $4-3$ と同様に局所温度係数 $\kappa$ が平面半球で一定と見なし、放射温 度で積算する方法も考えられる。

$$
M R T_{\text {plate }, T}=\sum_{\text {plate }} \Psi\left\{d A_{p} \rightarrow A_{r i}\right\} T_{r i}
$$

\section{4-6. 本計測システムの特徽}

放射強度を積算して求めた平均放射温度 $M R T_{\text {sphere,I }}$ および

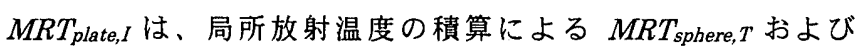

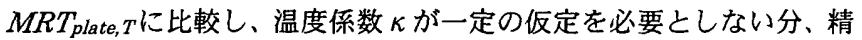
度が高いと言える。したがって、以降の分析では放射強度の積算に よる方法を用いることとする。しかし、4 乗則で表されるので線形 的な取り扱いはできなくなる。中村は、立方体の各面周りの平均放 射強度を計測し、該当方向に対して均一な放射強度を仮定して放射 束ペクトルを推定する方法により、任意方向の「局所平均放射温度」 を算出する方法を示した 6)。本計測システムは、放射束ベクトルを直
接計測するものであると言え、全球的な放射強度デー夕を任意の方 向を向いた平面周りの平均放射温度、すなわち「局所平均放射温度」

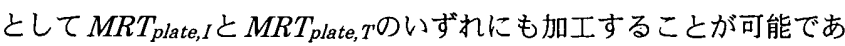
る。その際、関係する方向の放射強度の実測值に基づいた積算を行 うので実態に即した值が得られるのが特徴である。

\section{5. 放射強度分布の実態調查}

夏期の屋外空間にて、放射強度の連続的分布の実態調查を実施し た。計測は樹林 1 箅所および住棟間 3 箇所で行った。計測期間は平 成 8 年 9 月 9 日、計測場所は福岡市貝塚の団地抽よび大学キャンパ スである。樹林の地表面は草地、住棟間の地表面はそれぞれ打ち水 を施した保水性セラミック舖装、保水性セラミック舗装、アスファ ルト舖装である。以降、これらの計測箇所を $\mathrm{F}$ （樹林）、W（住棟 間、地表が湿りセラミック）、C（住棟間、地表がセラミック）、 A（住棟間、地表がアスファルト）と称する。各計測筫所の様子を 写真 $2 \sim 5$ に示す。各測定個所にて放射強度分布および気温、日射 等の気象条件を順次計測した。気温、湿度は日陰にてアスマン乾湿 度計を用いて計測を行った。放射強度の計測は人体への放射熱影響 を検討するため、地上 $1.5 \mathrm{~m}$ 高さにおいて行った。同様の位置にて黒 球温度の計測も合わせて行った。黒球は直径 $75 \mathrm{~mm}$ のものを用い、 応答性の確保に努めた。太陽位置に該当する計測メッシュでは搭载 した短波センサの適用限界を越えたため、全天日射計の值から太陽 位置のメッシュ以外の放射熱量テータの総和を差し引き、当該メッ シュの放射強度を見積もった。気象条件の一覧を表 2 に示す。当日 の天候は薄農りの晴れ日であった。実測日以前の 1 週間は晴れ日も しくは薄骨りの安定した天候状況であった。

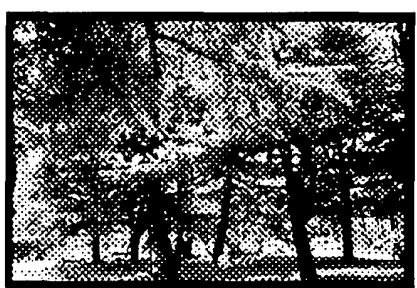

写真 2 計測簓所 F の蛔景

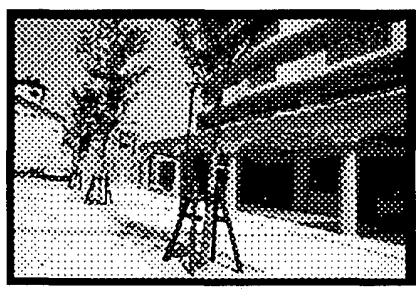

\begin{tabular}{|c|c|c|c|c|c|c|c|}
\hline & ${ }^{\circ} \mathrm{C}$ & ${ }^{\circ} \mathrm{C}$ & $\%$ & $\mathrm{~kg} / \mathrm{kg}^{\prime}$ & $\mathrm{W} / \mathrm{m}^{2}$ & ${ }^{\circ} \mathrm{C}$ & $\mathrm{m} / \mathrm{s}$ \\
\hline 計测個所 & 乾球温 & 湿球温 & 相対湿度 & 湿合比 & 全天日射量 & 黒球温度 & 風速 \\
\hline$F$ & 32.0 & 26.1 & 63.0 & 0.0190 & $46.0 / 736.0$ & 32.4 & 0.15 \\
\hline $\bar{w}$ & 30.2 & 25.9 & 72.0 & 0.0195 & 869.0 & 39.2 & 2.60 \\
\hline c & 30.3 & 25.4 & 68.0 & 0.0185 & 907.0 & 43.1 & 3.20 \\
\hline A & 30.4 & 25.8 & 68.0 & 0.0190 & 916.0 & 38.7 & 3.83 \\
\hline
\end{tabular}

写真 4 計測簓所Cの国景

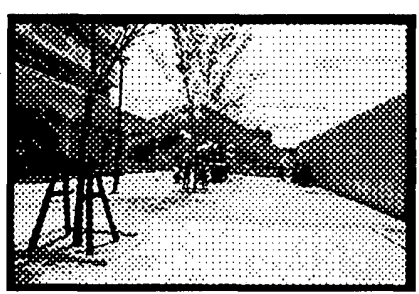

写真 3 計測簓所Wの風景

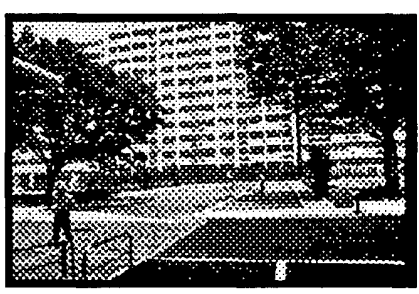

写真 5 計測筒所 Aの風景
表 2、気象条件

*計測箅所 $\mathrm{F}$ の全天日射量は樹林内外の雨方の值を示してある 


\section{6. 計溉结畏と得察}

\section{6-1. 旗射強茞分棉}

住植間（計測箇所 A）と樹林（計測箇所 F）を例として、放射熱 環境を比較する。各々の天空側魚眼写真を写真 6 〜 7 に示す。これ らの魚眼写真と同様な位置関係で短波および長波の放射強度分布を 可視化したのが図 3〜6である。分布の表示に際しては線形補間で スムージングを施してある。このようなグラデーション表示は分布 の判別し易さに役立つものであるが、データの解像度とは必ずしも 合致していない点に留意する必要がある。図 3 および図 4 に示され る記号は、A-1：太陽、A-2：雲、A-3：青空、A-4：建物壁に相 当する計測メッシュを示す。図 5 および図 6 に示される記号は F$1:$ 樹冠、F-2:樹冠の切れ間に相当する計測メッシュを示す。こ れらの計測メッシュは地物単位の比較を行うため、センサの立体角 を考慮し注1)、A-1：太陽のメッシュを除き他の地物が混在していな いものを選定した。図中の数值は各計測メッシュにおける放射強度 を表すものである。図中に記裁した地物と天空の境界線は放射強度 のコントラストとほほ一致していることが分かる。局所的な放射強 度の特徵を以下に述べる。太陽位置（A-1）では短波、長波ともに 最大値を示し、特に短波の值は桁違いに大きい。太陽周辺の雲域 （A-2）においては短波、長波ともに大きめの值を示す。一方、太 陽位置から外れた骨空（A-3）では短波の値は雲域のものよりかな り小さくなり、長波の值は最小值を示す。大気特有の放射特性の影 考えられる。建物壁（A-4）、樹冠（F-1）では、短波の值が小 さいため、長波の值は青空（A-3）のものよりも大きいものの、短 波、長波の合計值は青空（A-3）より低い。樹冠の切れ間（F-2）の 值は短波、長波ともに雲域（A-2）と同程度の值が得られた。

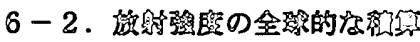

式(8.a),(8.b)を用いて球周りの長波および短波の放射強度を半球 および全球で浣算し、図 7 に整理した。図中に示す「shortる」，「long り」は天空側半球における短波および長波の半球平均放射強度、

「short个」，「long 个」は地表面側半球における短波および長波の 半球平均放射強度、「total」は短波、長波の放射強度の和を全球で 玟算した全球平均放射強度の值である。「total」が最小值を示した のが計測简所 Fである。主因は樹冠の日射遮蔽により、天空側の半

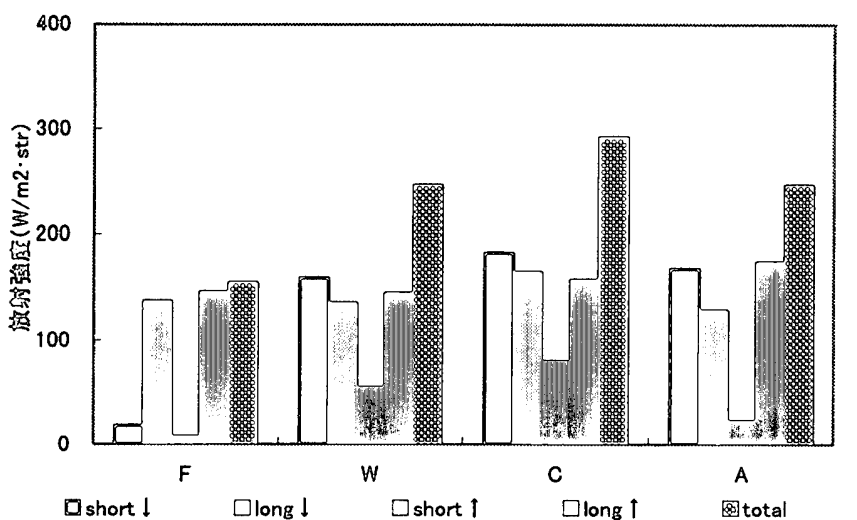

図 7 球周りの半球平均、全球平均の放射強度（地上 $1.5 \mathrm{~m}$ ）

$\left[\begin{array}{l}\mathrm{F}: \text { 樹林 (草地)、W : 住栖間（湿りセラミック） } \\ \mathrm{C}: \text { 住植間（セラミック）、A：住曺間（アスファルト） }\end{array}\right.$ 球平均放射強度「short $\downarrow$ がきわめて小さいことがあげられる。

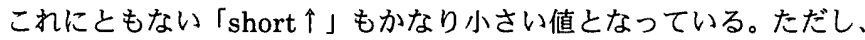

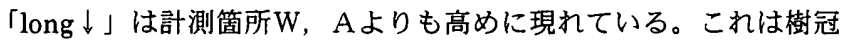
部の放射強度が天空と比較して高いことを示している。天空の放射 強度が低い理由としては大気の赤外波長域の透過性も一因と考えら れる。なお、樹冠の温度レベルはアスファルト等の地表面と比較す ると高くない。むしろ日射を受けながらも樹冠の温度上昇は抑制さ れていると考えるのが妥当である。計測箇所Wの「short 个」,「long 个」は計測箅所Cのものよりも小さい。後述の天候変化の影響に加 え、打ち水による日射吸収率の増加、蒸発冷却による表面温度の低 下も一因であると考えられる。計測箇所 Aでは、「long 个」の值が 大きく、アスファルト面の高温化を裏付けているが、その一方「short 个」の值はかなり小さい。その結果、「total」の值は計測箇所Cの ものよりも小さい。総熱量で見た場合、照り返し日射の影響は無視 できないことが分かる。

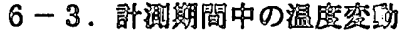

気温と表面温度の時間変動を図 8 に示す。図中、矢印で示した期 間は計測実施期間を示すものである。全体的に急激な天候の変化は ない。計測箅所Cの計測時においては晴れ間が司覞いたため気温、表 面温度ともに若干の温度上昇が見られた。

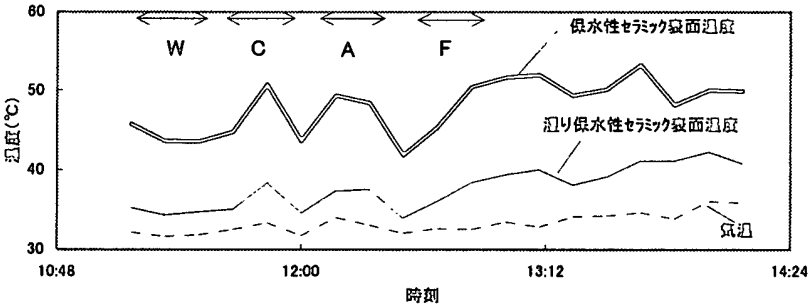

図 8 計測期間中の温度変動

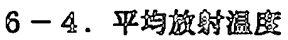

短波、長波の放射強度の和を全球で積算し平均放射温度を見䅡も った。計算式は(11.b)を用いた。平均放射温度は実際の温度場とは 異なるが、総熱量の俨価には有効と考えられる。平均放射温度の值 は、Fでは $31.1^{\circ} \mathrm{C}$ となり、気温の值 $32.0^{\circ} \mathrm{C}$ と同程度になった。日射 のある住棟空間では気温を大きく上回る結果が得られた。平均放射 温度の值はWで $69.0^{\circ} \mathrm{C} 、 \mathrm{C}$ で $83.7^{\circ} \mathrm{C} 、 \mathrm{~A}$ で $68.9^{\circ} \mathrm{C}$ を示した。屋外に おいては平均放射温度は気温と大きく乘離するため、対流と放射を 分離した解析が必要である。総合熱伝達率の問題点を再確認したと 言える。

また、屋外では放射温度のむらが大きい点に注意する必要がある。 図 9 は計測箇所Aにおける局所放射温度の頻度分布を局所温度係数 $\kappa\left\{A_{r i} \leftrightarrow g\right\}$ の值と合わせて表示したものである。局所温度倸数 $\kappa$ は局所放射温度および黒球温度の実測值を式(10)に代入して求め た。局所放射温度は広範囲に存在していることが分かる。ここには 示していないが日射位置に該当する計測メッシュでは $700^{\circ} \mathrm{C}$ 近い值 を示した社 2)。局所温度係数の值は、局所放射温度の違いにより影

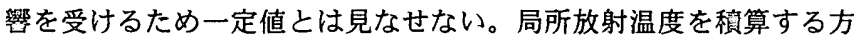
法で平均放射温度を推定する場合には代表的な放射熱伝達率を何ら かの形で求めておく必要がある。 


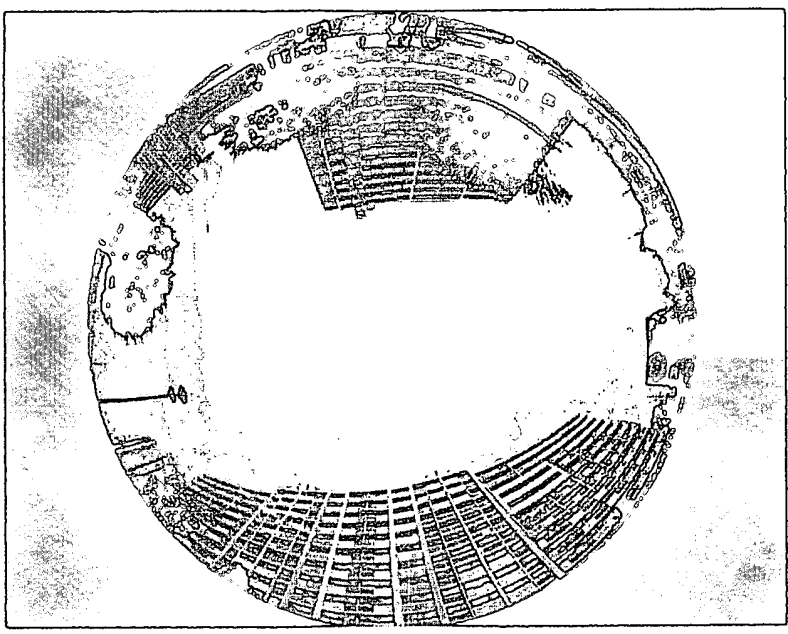

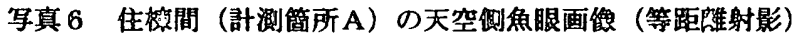
（上侧を南方位として表示）天空帮69\%

\section{放射強度}

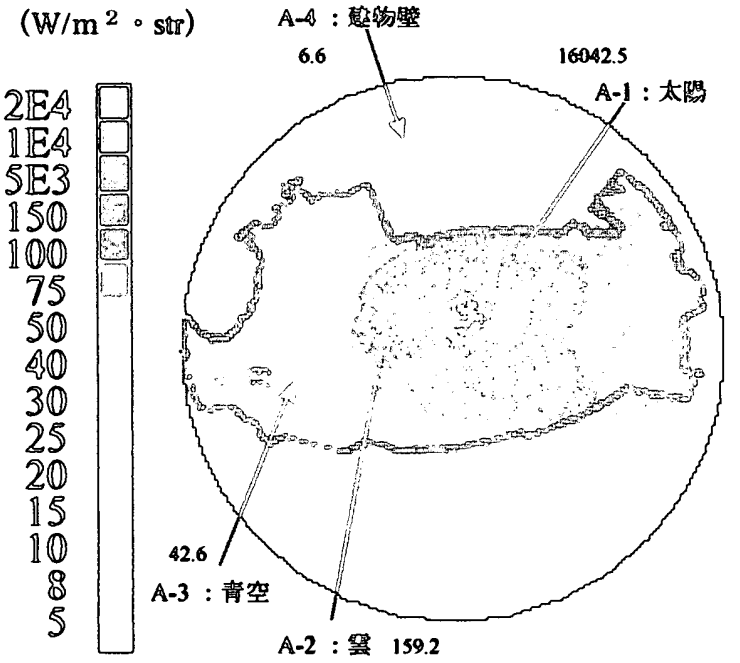

図 3 住椟間（計测簤所A）における天空側短波放射強度の分布 （上侧を南方位として表示）

\section{放射強度}

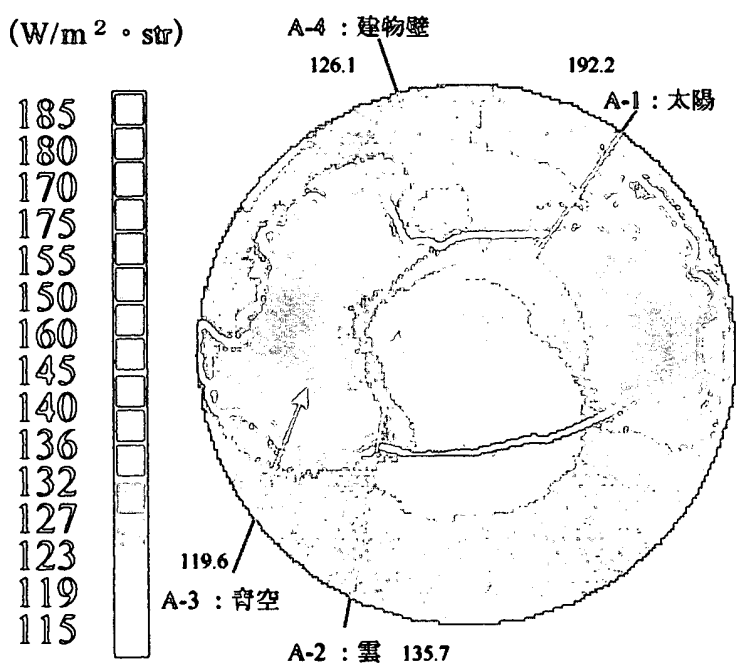

図 4 住柷間（計測简所A）における天空侧長波放射强度の分布

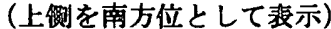

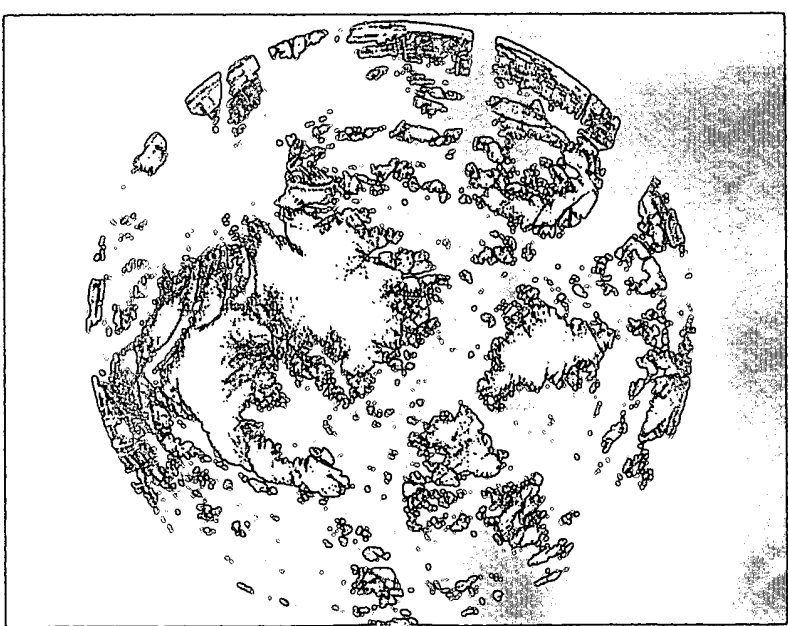

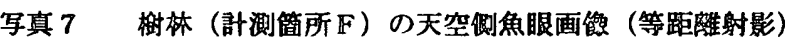
（上㑡を南方位として表示）灭空非 $9 \%$

放射㟋度

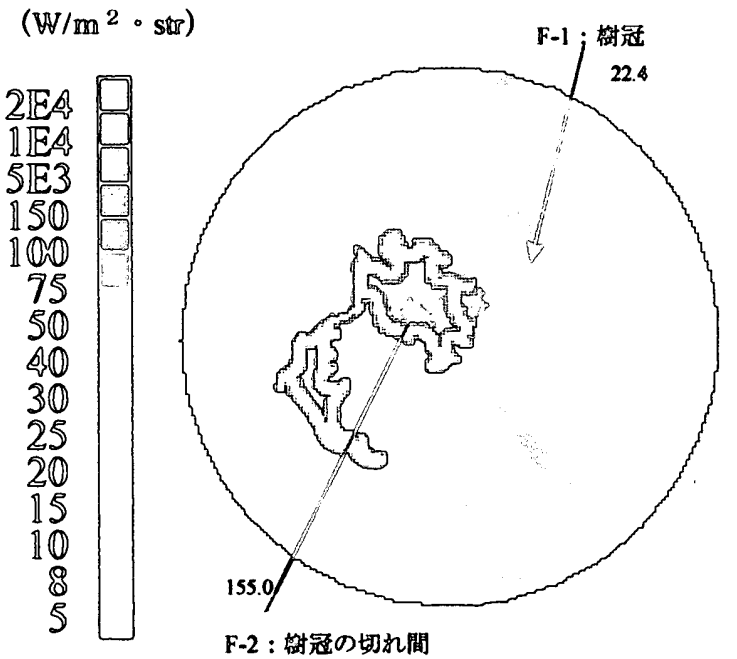

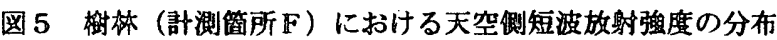
（上侧を南方位として跋示）

\section{放射強度}

$\left(\mathrm{W} / \mathrm{m}^{2} \circ \mathrm{str}\right)$
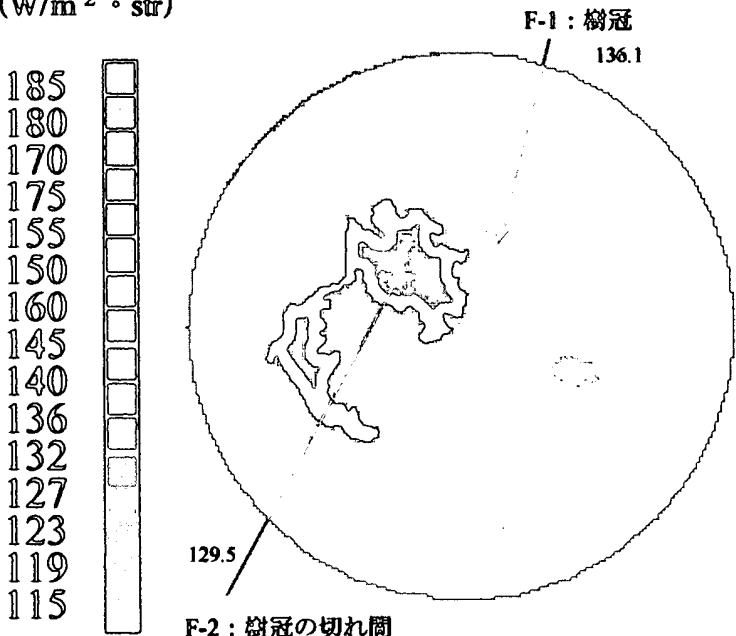

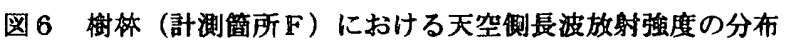
（上㑡を南方位として表示） 


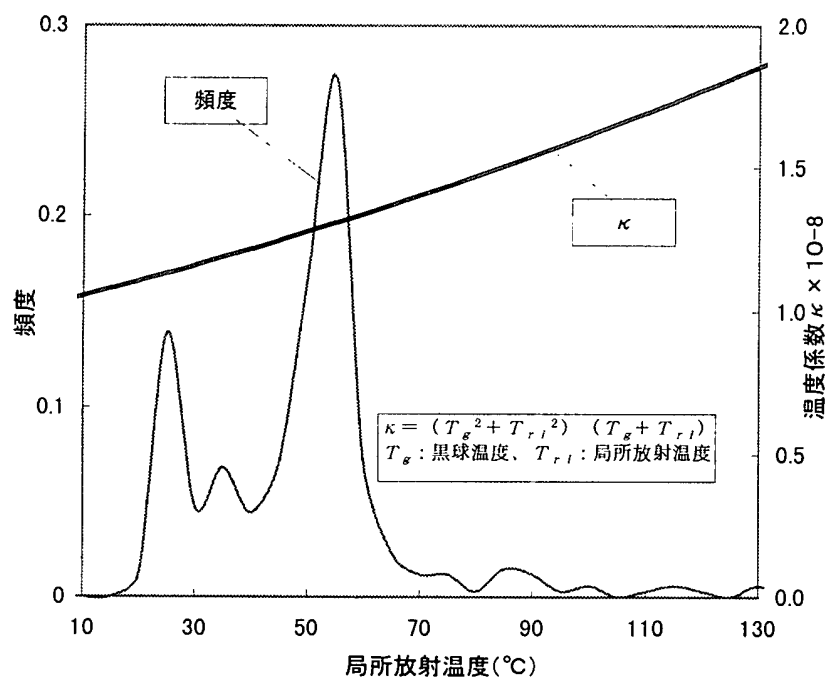

図 9 計測箇所 Aの局所放射温度の頻度分布

今回の結果を黒球の熱収支式から推定注 3) した平均放射温度の值 と比較して表したのが図 10 である。両者の開きは $7 \%$ 以内に収ま っており、変動の激しい屋外の気象状況下での計測であったのにも 関わらず良好な一致を見せた。黒球温度は各測定箇所にて 5 分間の 目読を行い安定した時の値を用いた。 $150 \mathrm{~mm} \phi$ の黒球は 2 分程度 の平均化を行えばその間の気象条件を反映すると言われている 8)。 今回の計測時間を勘案すれば平均化のプロセスに検討の余地を残し ているものの $75 \mathrm{~mm} \phi$ 黒球の応答性は十分であると考えられる。放 射強度の全球計測の間には気象状況も変化しているが、結果的には 妥当な值が得られているようである。今回の計測における気候変動 であれば、本計測システムは総熱量の評伍に有効であると思われる。

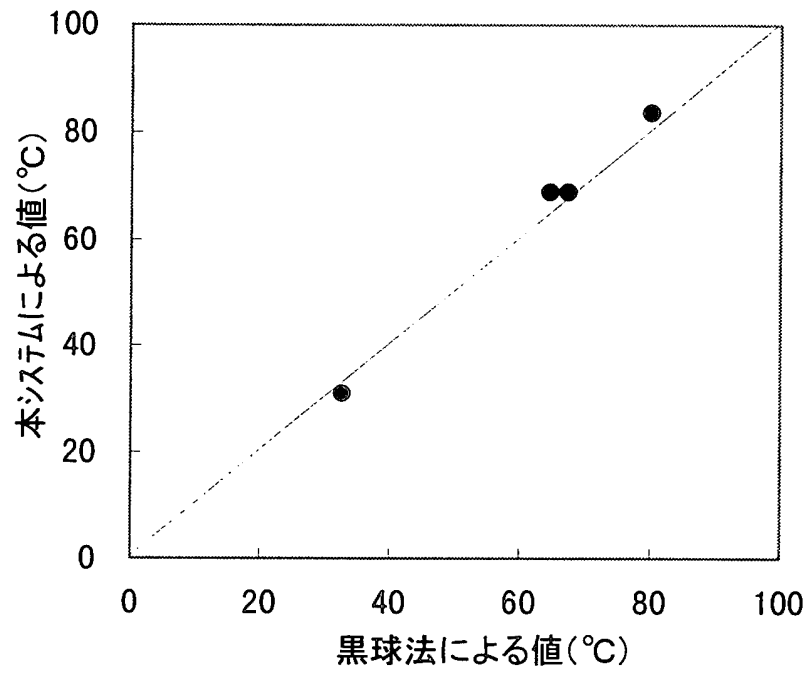

図 10 球周りの平均放射温度に関する 黒球法と本システムの比較

\section{5 平面放射熱流束}

地上 1.5 m高さに位置する平面周りの長波および短波の放射熱流 束の集計結果を表 3 に一覧する。放射熱流束は式(15)から得られる $I_{s, \iota}$ (plate\}に にを乗じた値を用いた。表中に示す「LONG $\downarrow 」 ，$
「SHORT」」は天空側平面における長波および短波の放射熱流束、

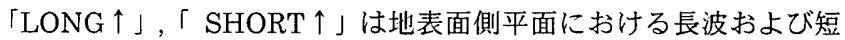
波の放射熱流束である。魚眼画像から求めた各計測箇所の天空率は F : 9\%、W : 62\%、C : 61\%、A : 69\%である。F、W、Cにおけ る「LONG $\downarrow 」 の$ 值は $430 \sim 520 \mathrm{~W} / \mathrm{m}^{2}$ の值を示す。通常の夏季の大 気放射量よりも若干高い值を示している。天空率から考えて周辺地 物の影響を $30 \sim 40 \%$ 含むものである。下向き魚眼画像を調べると全 ての計測箇所にて地表面の形態係数は 0.95 を越えている。したがっ

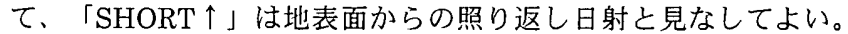

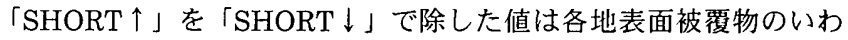
ゆるアルベド値となる。その值は、F（地表が草地）：0.26、W（地 表が湿りセラミック）：0.24、C（地表がセラミック）：0.33、A (アスファルト)：0.06である。

表 3 平面放射熱流束の計測結果

単位: $\mathrm{W} / \mathrm{m}^{2}$

\begin{tabular}{|c|r|r|r|r|}
\hline 計測個所 & LONG $\downarrow$ & SHORT $\downarrow$ & LONG $\uparrow$ & SHORT $\uparrow$ \\
\hline F & 433.8 & 72.9 & 459.1 & 19.2 \\
\hline W & 428.5 & 869.0 & 470.4 & 200.0 \\
\hline C & 517.7 & 907.0 & 491.7 & 290.4 \\
\hline A & 412.7 & 916.0 & 550.1 & 59.9 \\
\hline
\end{tabular}

\section{7. 結論}

1）平面および球周りの平均放射温度の計算方法として放射強度 を積算する方法と局所放射温度を積算する方法を示した。

2) 太陽近傍、建物壁、樹冠等の局所的な放射強度を実測し、波長 毎の特徵を明らかにした。

3）放射強度の積算による平均放射温度の值を黒球の熱収支式か ら推定した值と比較し、本計測システムの総熱量評価に関する 有効性を確認した。

謝辞 住宅都市整備公団九州支店には計測場所を提供いただいた。实測にあた っては、青木建設株式会社九州支店、青木建設株式会社研究所、埼玉大学建設 学科ヴタン力助教授、九州大学農学部鈴木義則研究室に協力を得た。また、大 気の放射特性に関しては大林組技術研究所の大塚清敏氏に貴重なご意見をいた だいた。記して感謝の意を表します。

注 1 ）今回の計測メッシュの立体角は $0.0326 \sim 0.1207 \operatorname{str}$ の範囲にあり、いず れもセンサの立体角 0.0289str より大きな値である。

注 2）センサの開口角の中で太陽の占める割合を考豦し、計測筬所Aにおける 放射強度デー夕を太晹の放射温度に換算すると、4417 Kになる。これは、法線

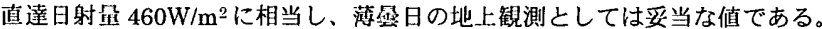

注 3）黑球の熱収支は次式で表される。

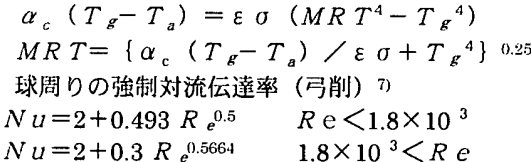

記号説明

$Q\left\{A_{1} \rightarrow A_{2}\right\}: A ，$ から $A$ ，に入射する放射熱量（W） $Q\left\{A_{1} \leftrightarrow A_{2}\right\}: A_{2}$ が $A_{1}$ と交換する放射熱收支量 (W) $I\left\{\mathrm{~A}_{1}\right\}: A_{1}$ における放射強度 $\left(\mathrm{W} / \mathrm{m}^{2} \cdot \mathrm{str}\right)$

$T:$ 温度 $(\mathrm{K})$

$T_{r i}:$ 局所放射温度 $(\mathrm{K})$

$M R T:$ 平均放射温度 $(\mathrm{K})$

$T_{a}:$ 気温 $(\mathrm{K})$ 
$V:$ 電圧 (Volt)

$A:$ 面積 $\left(\mathrm{m}^{2}\right)$

$\mathrm{D}$ : 日射减衰係数

C : センサ定数

$\eta:$ センサ定数

$\Psi\left\{A_{1} \rightarrow A_{2}\right\}: A_{1}$ 出ら $A_{2}$ を見た形態保数

$\Omega\left(d A_{p} \rightarrow A_{r i}\right): d A_{p}$ から見た $A_{r i}$ の立体角の投影

$\Omega\left(g \rightarrow A_{r i}\right): g$ 只ら見た $A_{r j}$ の立体角

$\kappa\left\{A_{1} \leftrightarrow A_{2}\right\} \quad: A_{1}$ と $A_{2}$ の 2 面間における局所温度係数 $\kappa=\left(T_{A}{ }^{2}+T_{A Z^{2}}\right)\left(T_{A I}+T_{A 2}\right)$

$\alpha_{c}$ : 熱伝達率 $\left(\mathrm{W} / \mathrm{m}^{2} \mathrm{~K}\right)$

$\sigma$ : ステファンボルツマン定数 $\left(\mathrm{W} / \mathrm{m}^{2} \mathrm{~K}^{4}\right)$

$\varepsilon$ : 黒球の放射率 $\varepsilon=1.0(-)$

$N u:$ ヌッセルト数 $N u=\alpha_{c} \mathrm{~d} / \lambda$

$\mathrm{d}:$ 黒球直径 $(\mathrm{m})$

$\lambda:$ 空気の熱伝導率 $(\mathrm{W} / \mathrm{mK})$

$R e:$ レイノルズ数 $R=\omega \mathrm{wd} /$

$w$ : 風速 $(\mathrm{m} / \mathrm{sec})$

$\nu:$ 動粘性俰数 $\left(\mathrm{m}^{2} / \mathrm{sec}\right)$

添え字

$s:$ 短波

८:長波

$r:$ 周聿

$\mathrm{r} i ：$ 周囲のメッシュ分割

$\mathrm{g}:$ 微小球

$\mathrm{p}:$ 半球の接平面上の微小面
参考文献

1) KATAYAMA, T. and MORIKAWA, A. and MASUDA, S. : Investigation on the Formation of Thermal Environment in an Urban Canyon, Journal of Transaction of AIJ, NO. 372, pp.30-41, 1987

2) BROWN, R. D: and Gillespie, T. J. : Estimating Outdoor Thermal Comfort Using a Cylindrical Radiation Thermometer and an Energy Budget Model, Int. J. Biometeor., Vol.30, No.1, PP.43-52, 1986

3）梅干野鼠、何江 : 屋外熱賈境計の試作とその検討、日本建築学会計画系論 文集、NO.388、PP.29-37、1988.6

4）孫章烈、磯田㶳生、松井昌幸、小林陽太郎 : 単純形態と襄境亡の間の熱交 換による温熱睘境の総合評価に関する研究 (第 1 報 温度降下状態におけ る黒盜り球に対する環境の冷却力)、日本建築学会計画系論文集、1981.1、 PP.83-94

$5 ）$ 中村泰人 : 人間熱一舆境系（3.10 舞境ふく射の計測）、日刊工業新聞社、 PP.207-213、1989

6 ）中村泰人:建築都市空間内の人体に対する熱放射場の表現方法について、 日本建築学会計画系論文集、NO.376、PP.29-35、1987.6

7 ) T.YUGE, Experiments on Heat Transfer of Spheres/ Report 3,Rep. Inst. High Sp. Mech., Japan, Vol.11, 1959/1960, No.108, p.217

8 ）片山忠久ら:放射環境下における気温およびグローブ温度の測定精度に関 する実豎的研究、日本建築学会計画系論文集、No.381、pp.20.26、1981.1

（1996年12月 2 日原稿受理，1997年 5 月16日採用決定） 